\title{
Synthesis and study of photosensitive chromone derivatives for recording media of archival three-dimensional optical memory
}

\author{
Mikhail M. Krayushkin, ${ }^{\mathrm{a} *}$ Konstantin S. Levchenko, ${ }^{\mathrm{a}}$ Vladimir N. Yarovenko, ${ }^{\mathrm{a}}$ \\ Igor V. Zavarzin, ${ }^{a}$ Valery A. Barachevsky, ${ }^{\text {Y }}$ Yury A. Puankov, ${ }^{\text {Tatyana M.Valova, }}$ \\ and Olga I. Kobeleva ${ }^{\text {b }}$ \\ ${ }^{a}$ N. D. Zelinsky Institute of Organic Chemistry, Russian Academy of Sciences, 47 Leninsky \\ prosp., 119991 Moscow, Russian Federation \\ ${ }^{b}$ Photochemistry Center, Russian Academy of Sciences, 7a ul. Novatorov, 119421 Moscow, \\ Russian Federation \\ E-mail: mkray@mail.ioc.ac.ru
}

\begin{abstract}
The synthesis and photochemical study of 3-acetyl-2(2'-furyl)chromone derivatives are described, which are of interest for the creation of photo-induced irreversible luminescent media for one-time superdense recording on a multilayer carrier. New thiophene-containing 3-acetyl2(2'-furyl)chromone derivatives are prepared with examples of their chemical modification and their photochemical properties studied, including spectral data for the individual substances and those incorporated in polymeric matrices. These show prospects as light-sensitive components of recording media for archival three-dimensional optical memory.
\end{abstract}

Keywords: Chromones, thiophenes, photochemical investigation, polymeric matrices

\section{Introduction}

Chromone derivatives are abundant in nature and possess a wide range of biological and pharmacological activity. ${ }^{1}$ Chromones are studied as antioxidants, ${ }^{2}$ substances that favor healing of wounds ${ }^{3}$ and ulcers, ${ }^{4}$ immunostimulators, ${ }^{5}$ and as anti-HIV agents. ${ }^{6}$ Many chromone derivatives are also photoactive and can be used easily in various photoinduced reactions affording diverse heterocyclic compounds. ${ }^{7}$ Derivatives of 2-furyl-3-acetylchromones are of interest as photosensitive organic systems designed for use in various photocontrolled photonic devices. 2-Furyl-3-acetylchromones undergo irreversible changes under UV irradiation to form photoluminescent products providing optical information reading (Scheme 1). ${ }^{8}$ However, the photochemical characteristics of the known chromones (mainly, benzoyl derivatives) only partially satisfy the requirements imposed on irreversible photoluminescent media by absorption 
wavelengths, light-sensitivity, and fluorescence intensity. An analysis of published data showed that the bathochromic shift is caused by the introduction of donor substituents into both the acetyl and furan fragments of this group of chromones, which pre-determined the use of thienyl substituents.

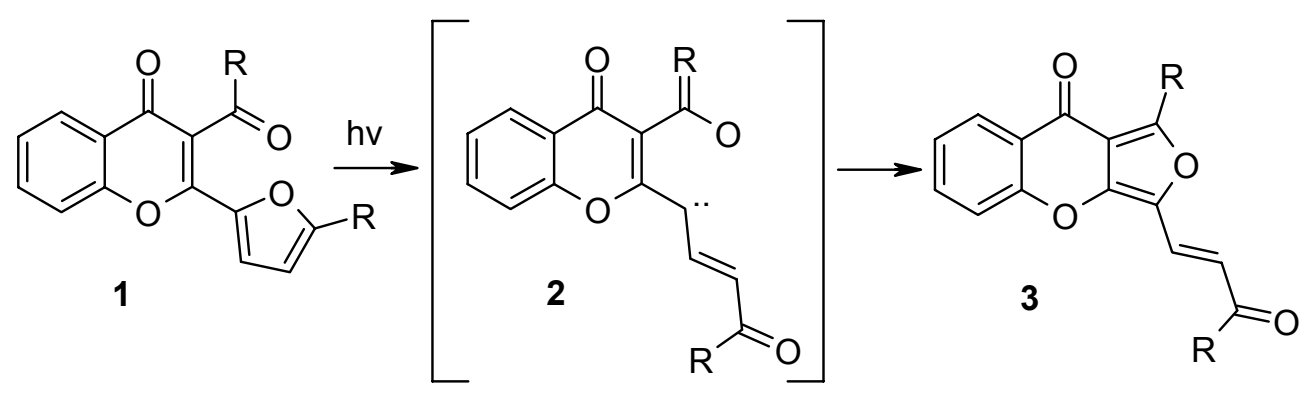

\section{Scheme 1}

Several methods for the synthesis of 2-furyl-3-acetylchromones have been described. The simplest is the synthesis of 3-aroylflavone using the one-pot reaction of 2-hydroxyacetophenone with furancarboxylic acid anhydride in the presence of triethylamine. ${ }^{8}$ A similar reaction involving 2,4-dihydroxy-5-nitroacetophenone and benzoyl chloride and $\mathrm{K}_{2} \mathrm{CO}_{3}$ has been described. ${ }^{10}$ However, this route is restricted by the possibility of obtaining only compounds $\mathbf{1}$ with identical Ar substituents and a substituent in position 2. In another approach developed by Richard T. Commings and coworkers, ${ }^{9}$ 1-(2-hydroxyphenyl)-3-arylpropane-1,3-diones are acylated in the presence of $N, N$-dimethyl-4-amino pyridine (DMAP) and pyridine and then undergo ring-closure to form chromones in the presence of 1,8-diazabicyclo[5.4.0]undec-7ene(1,5-5) (DBU).Some examples of the synthesis of chromones from 1-(2-hydroxyphenyl)-3arylpropane-1,3-dione and aliphatic acid anhydrides in the presence of bases, such as sodium hydride ${ }^{11}$ or the acid's sodium salt of are known. ${ }^{11,12}$ It was shown that 2-aryl-3-acyl-substituted chromones can be synthesized by the oxidation with selenium dioxide of the product of crotonic condensation of 1-(2-hydroxyphenyl)-3-arylpropane-1,3-dione with aldehydes. ${ }^{8}$ The methods described in the literature were not used for the synthesis of thiophene-containing derivatives of 3-acetyl-2-(2'-furyl)chromone.

\section{Results and Discussion}

We studied the approaches to 2-furyl-3-acetylchromone derivatives based on the acylation of 1(2-hydroxyphenyl)-3-arylpropane-1,3-diones followed by ring closure by DBU, and the oxidation with selenium dioxide of the product of crotonic condensation of 1-(2-hydroxyphenyl)3-arylpropane-1,3-dione with aldehydes. It was found that the latter method (Scheme 2) makes it 
possible to synthesize chromones in high yields. However, this approach makes it possible to synthesize in high yields only chromones containing the benzene moiety in position 3 . The introduction of the thiophene fragment decreases sharply the yield of the products in the step of crotonic condensation. To enhance the yields in this step, we studied the effect of temperature and bases on the yields of the condensation product. It turned out that bases $\left(\mathrm{CH}_{3} \mathrm{COONa}\right.$, morpholine, triethylamine, piperidine) exert no substantial effect on the reaction. At the same time, the temperature effect is very substantial. It should be mentioned that the yields of the target product $\mathbf{1 0}$ are independent of the ratio of isomers $\mathbf{8}$ and $\mathbf{9}$ and, most likely, that ring closure of compound $\mathbf{8}$ to the isomeric product $\mathbf{9}$ proceeds smoothly under the conditions of oxidation with selenium dioxide.

We have shown that a reduction in the reaction temperature considerably enhances the yields of products of aldol condensation, which are $70-80 \%$ at temperatures from -10 to $15{ }^{0} \mathrm{C}$.

To study the influence of the nature of heterocycles on the photochemical properties of the compounds we synthesized a wide series of chromones using our improved approach. In addition to the thiophene derivatives containing donor substituents, we also synthesized their benzeneand furan- containing analogs (Figure 1).<smiles>[R]c1ccc(O)c(C(C)=O)c1</smiles><smiles>[R]c1[X]c(C=C(C(=O)Br)C(=O)c2cc([R])ccc2[R])cc1</smiles>
a. $\mathrm{R}=\mathrm{H}, \mathrm{R}_{1}=\mathrm{H}, \mathrm{Ar}=\mathrm{Ph}, \mathrm{X}=\mathrm{O}$
h. $\mathrm{R}=\mathrm{H}, \mathrm{R}_{1}=\mathrm{H}, \mathrm{Ar}=2$-Furyl, $\mathrm{X}=\mathrm{O}$
b. $\mathrm{R}=\mathrm{H}, \mathrm{R}_{1}=\mathrm{Me}, \mathrm{Ar}=\mathrm{Ph}, \mathrm{X}=\mathrm{O}$
i. $\mathrm{R}=\mathrm{H}, \mathrm{R}_{1}=\mathrm{Me}$, Ar=2-Furyl, $\mathrm{X}=\mathrm{O}$
c. $\mathrm{R}=\mathrm{H}, \mathrm{R}_{1}=\mathrm{H}, \mathrm{Ar}=\mathrm{Thiophene}-2-\mathrm{yl}, \mathrm{X}=\mathrm{O}$
j. $\mathrm{R}=\mathrm{H}, \mathrm{R}_{1}=\mathrm{NO}_{2}, \mathrm{Ar}=\mathrm{Ph}, \mathrm{X}=\mathrm{O}$
d. $\mathrm{R}=\mathrm{Me}, \mathrm{R}_{1}=\mathrm{H}, \mathrm{Ar}=$ Thiophene-2-yl, $\mathrm{X}=\mathrm{O}$
k. $\mathrm{R}=\mathrm{H}, \mathrm{R}_{1}=\mathrm{H}, \mathrm{Ar}=\mathrm{Ph}, \mathrm{X}=\mathrm{S}$
e. $\mathrm{R}=\mathrm{H}, \mathrm{R}_{1}=\mathrm{H}, \mathrm{Ar}=5$-Methylthiophene-2-yl, $\mathrm{X}=\mathrm{O}$
l. $\mathrm{R}=\mathrm{H}, \mathrm{R}_{1}=\mathrm{Me}, \mathrm{Ar}=5$-Methyl-thiophene-2-yl, $\mathrm{X}=\mathrm{O}$

f. $R=M e, \quad R_{1}=H, A r=5-M e t h y l t h i o p h e n e-2-\quad m . R=H, R_{1}=H, A r=3-N_{2}-P h, X=O$ $\mathrm{yl}, \mathrm{X}=\mathrm{O}$

g. $\mathrm{R}=\mathrm{H}, \mathrm{R}_{1}=\mathrm{Me}, \mathrm{Ar}=$ Thiophene-2-yl, $\mathrm{X}=\mathrm{O}$

\section{Scheme 2}


<smiles>[R]c1ccc2oc(-c3ccc([R])o3)c(C(=O)c3ccccc3)c(=O)c2c1</smiles><smiles>[R]c1ccc2oc(-c3ccc([R])o3)c(C(=O)c3ccco3)c(=O)c2c1</smiles>

\section{Figure 1}

Among the synthesized products, in the compounds (10 k) the furan ring was substituted for the thiophene ring (Figure 2). Note that a few examples are described for the modification of 3 acetyl-2(2'-furyl) chromones with retention of the major heterocycle, and no data on the transformations of the carbonyl group are available. In order to study a correlation between the structure of the functional framework and the photochemical properties, we carried out the selective replacement of the pyran carbonyl by thiocarbonyl, which occurs in the presence of an equivalent amount of phosphorus pentasulfide.<smiles>O=C(c1ccccc1)c1c(-c2cccs2)oc2ccccc2c1=O</smiles>

\section{Figure 2}

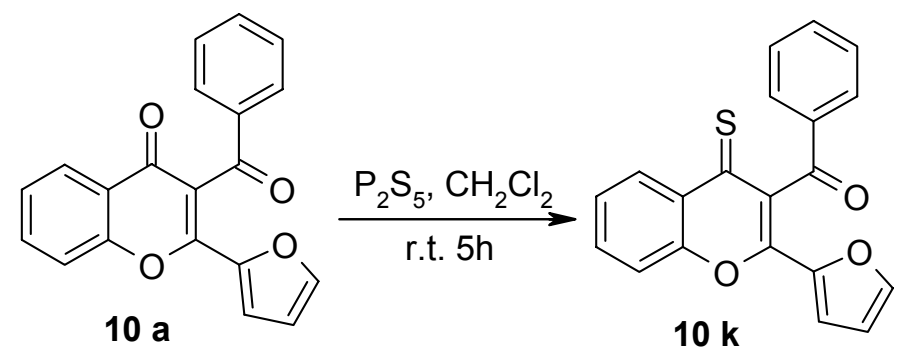

\section{Scheme 3}

The data for the preliminary photochemical investigation of the synthesized products (10a-n) (Figure 3) are given in Table 1. 


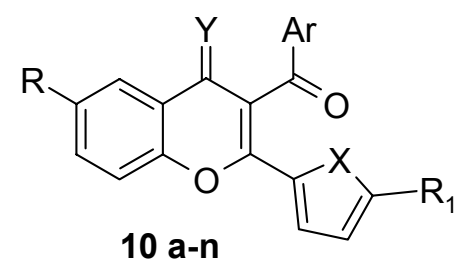

\section{Figure 3}

Table 1. Photochemical properties of chromone derivatives in toluene

\begin{tabular}{|c|c|c|c|c|c|c|c|c|c|c|}
\hline 10 & $\mathrm{R}$ & $\mathrm{R}_{1}$ & $\mathrm{Ar}$ & $\mathrm{X}$ & Y & $\begin{array}{c}\lambda_{\mathrm{A}}{ }^{\max } \\
\mathrm{nm}\end{array}$ & $\begin{array}{c}\lambda_{\mathrm{B}}^{\max } \\
\mathrm{nm}\end{array}$ & $\begin{array}{c}\lambda_{\mathrm{B}}{ }^{\mathrm{fl}, \max } \\
\mathrm{nm}\end{array}$ & $\Delta \mathrm{D}_{\mathrm{B}}{ }^{\text {phot }}$ & $\begin{array}{l}\Delta \mathrm{I}_{\mathrm{B}}{ }^{\mathrm{fl}} \\
\text { a.u. }\end{array}$ \\
\hline $\mathbf{a}$ & $\mathrm{H}$ & $\mathrm{H}$ & $\mathrm{Ph}$ & $\mathrm{O}$ & $\mathrm{O}$ & 313 & $360 \mathrm{sh}, 415$ & 495 & 0.19 & 270 \\
\hline b & $\mathrm{H}$ & $\mathrm{Me}$ & $\mathrm{Ph}$ & $\mathrm{O}$ & $\mathrm{O}$ & 327 & $360 \mathrm{sh}, 415$ & 500 & 0.23 & 335 \\
\hline c & $\mathrm{H}$ & $\mathrm{H}$ & Thiophen-2-yl & $\mathrm{O}$ & $\mathrm{O}$ & 306 & 370,440 & 520 & 0.20 & 840 \\
\hline d & $\mathrm{Me}$ & $\mathrm{H}$ & Thiophen-2-yl & $\mathrm{O}$ & $\mathrm{O}$ & 313 & 375,440 & 520 & 0.24 & 730 \\
\hline e & $\mathrm{H}$ & $\mathrm{H}$ & $\begin{array}{l}\text { 5-Methyl- } \\
\text { thiophen-2-yl }\end{array}$ & $\mathrm{O}$ & $\mathrm{O}$ & 307 & 380,445 & 534 & 0.33 & 1000 \\
\hline f & $\mathrm{Me}$ & $\mathrm{H}$ & $\begin{array}{l}\text { 5-Methyl- } \\
\text { thiophen-2-yl }\end{array}$ & $\mathrm{O}$ & $\mathrm{O}$ & 310 & 380,445 & 530 & 0.25 & 880 \\
\hline g & $\mathrm{H}$ & $\mathrm{Me}$ & Thiophen-2-yl & $\mathrm{O}$ & $\mathrm{O}$ & 327 & 372,435 & 520 & 0.13 & 450 \\
\hline $\mathbf{h}$ & $\mathrm{H}$ & $\mathrm{H}$ & 2-Furyl & $\mathrm{O}$ & $\mathrm{O}$ & 310 & 368,425 & 505 & 0.19 & 672 \\
\hline $\mathbf{i}$ & $\mathrm{H}$ & $\mathrm{Me}$ & 2-Furyl & $\mathrm{O}$ & $\mathrm{O}$ & 325 & 373,425 & 510 & 0.20 & 310 \\
\hline $\mathbf{j}$ & $\mathrm{H}$ & $\mathrm{NO}_{2}$ & $\mathrm{Ph}$ & $\mathrm{O}$ & $\mathrm{O}$ & 335 & 365,425 & 500 & 0.11 & 45 \\
\hline $\mathbf{k}$ & $\mathrm{H}$ & $\mathrm{H}$ & $\mathrm{Ph}$ & $\mathrm{S}$ & $\mathrm{O}$ & 315 & 360,420 & 495 & 0.04 & 20 \\
\hline 1 & $\mathrm{H}$ & $\mathrm{Me}$ & $\begin{array}{l}\text { 5-Methyl- } \\
\text { thiophen-2-yl }\end{array}$ & $\mathrm{O}$ & $\mathrm{O}$ & 310 & 445 & 530 & 0,12 & 533 \\
\hline m & $\mathrm{H}$ & $\mathrm{H}$ & $\mathrm{C}_{6} \mathrm{H}_{4} \mathrm{NO}_{2}$ & $\mathrm{O}$ & $\mathrm{O}$ & 313 & 348,415 & 485 & 0.25 & 99 \\
\hline $\mathbf{n}$ & $\mathrm{H}$ & $\mathrm{H}$ & $\mathrm{Ph}$ & $\mathrm{O}$ & $\mathrm{S}$ & $\begin{array}{l}355 \\
400\end{array}$ & - & $495^{*}$ & - & $17^{*}$ \\
\hline
\end{tabular}

Footnotes. $\lambda_{A}{ }^{\max }$ and $\lambda_{B}{ }^{\max }$ are absorption maxima for the initial substance $\mathbf{A}$ and photoproduct $\mathbf{B}$, respectively; $\lambda_{\mathrm{B}}{ }^{\mathrm{fl}, \mathrm{max}}$ is the fluorescence maximum of the photoproduct $\mathbf{B} . \Delta \mathrm{D}_{\mathrm{B}}{ }^{\text {phot }}$ and $\Delta \mathrm{I}_{\mathrm{B}}{ }^{\mathrm{fl}}$ are the maximal photoinduced changes of optical density at the maximum absorption band of photoproduct B under irradiation with $\lambda=313 \mathrm{~nm}$, and the fluorescence intensity at the 
fluorescence maximum under excitation by irradiation adsorbed by photoproduct B at the maximum of the long-wavelength band in the photo-equilibrium state. * Are the fluorescence maximum and fluorescence intensity of the photo- inactive form of $\mathbf{1 0 n}$.

It was found that the synthesized compounds are irreversibly transformed in toluene solutions from the colorless initial form into the colored photoinduced form, excluding the compound $10 \mathrm{n}$.

The typical absorption and fluorescence spectra for one of the thienyl-substituted compounds at the photoequilibrium state are presented in Figure 4.

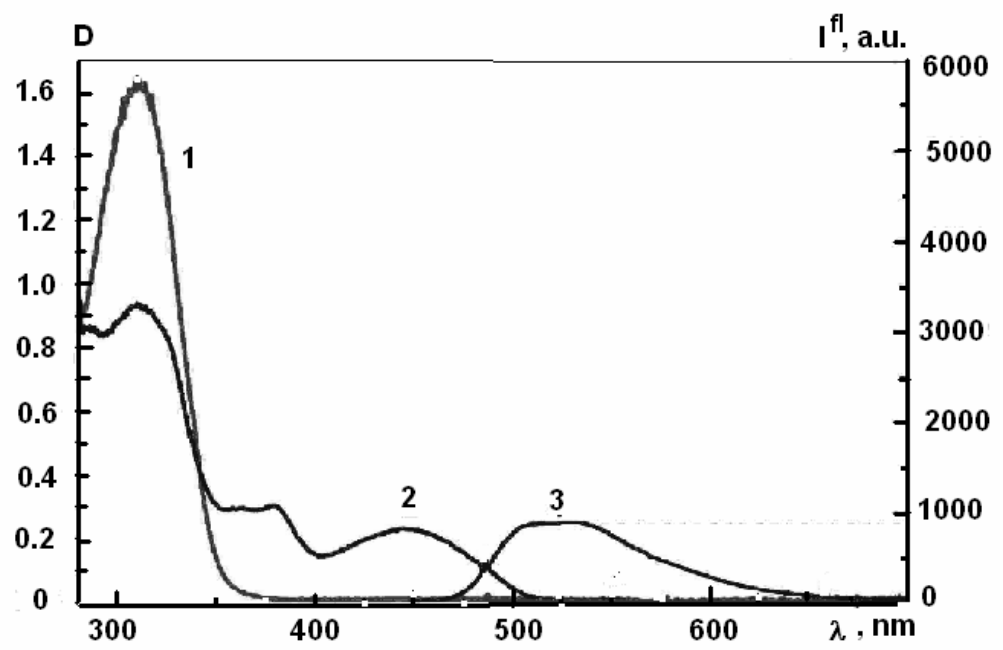

Figure 4. Absorption (1,2) and fluorescence (3) spectra before (1) and after (2,3) UV irradiation at the photoequilibrium state for compound $\mathbf{1 0 f}$ in toluene. The excitation irradiation of fluorescence is at $440 \mathrm{~nm}$.

The data in Table 1 and Fig. 3 show that of all the compounds two are characterized by a single absorption band for the initial form (Figure 4, curve 1). The photoproducts manifest two absorption bands (Figure 4, curve 2) and fluorescence (Figure 4, curve 3). The maximum longwavelength shift of the absorption band of the initial form of chromones is observed for the compound with the methyl- $(\mathbf{1 0 b}, \mathbf{1 0 g}, \mathbf{1 0 i})$ and nitro- $(\mathbf{1 0 j})$ substituents in the furan fragment. In contrast, the maximum long-wavelength shift of the absorption bands of the photoproduct is observed for the compounds with the thienyl fragment $(\mathbf{1 0 c - 1 0 g})$, especially with a methyl substituent in this fragment (10e, 10f). The compounds with two furan and phenyl fragments $(\mathbf{1 0 a}, \mathbf{1 0 b}, \mathbf{1 0 m})$ are characterized by the absorption spectra of the photoproducts, which are shifted toward the short-wavelength spectral region. Similar spectral shifts are observed for the maxima of the fluorescence bands (Table 1).

The kinetic study of the photoinduced change of optical density $\left(\Delta \mathrm{D}^{\text {phot, max }}\right)$ and the fluorescence intensity $\left(\Delta \mathrm{I}_{\mathrm{B}}{ }^{\mathrm{fl}}\right)$ showed some dependences between the efficiency of formation of 
the photoproduct as well as the fluorescence intensity and the structure of the synthesized compounds (Table 1). It should be emphasized that the formation of the photoproduct is accompanied, as a rule, by enhancement of the fluorescence intensity compared to other chromones. The least photo-induced changes of optical density and fluorescence intensity were found for the compounds $10 \mathbf{j}$ and $\mathbf{1 0 k}$.

It is interesting that UV irradiation of the compound 10n in toluene does not lead to the appearance of the photoproduct, but it manifests fluorescence under UV light. It is possible that this phenomenon is due to fluorescence of the initial form. Unlike those of other chromones, the spectrum of the initial form contains two absorption bands.

The data we have obtained allow us to choose certain chromones with the best characteristics for the development of photofluorescent recording media. The exact dependences will be determined in the future after the measurement of quantum yields for photochemical transformations and fluorescence.

We studied photochemical transformations of the synthesized compounds in polymeric matrices to develop photoluminescent recording media. The absorption and fluorescence spectra of one of the studied compounds in PMMA are shown in Figure 5. Unlike their behavior in solutions, the excitation of fluorescence by light at the maximum of the photoproduct's absorption band led to a very high fluorescence intensity (Figure 5). For this reason, that relative measurements of fluorescence intensity were carried out under UV light at $\lambda=300 \mathrm{~nm}$.

It turned out that among the studied polymeric bindings, poly(methyl methacrylate) provides the highest fluorescence intensity (Table 2). Judging from kinetic data $\left(\Delta \mathrm{D}_{\mathrm{B}}{ }^{\text {phot }}, \Delta \mathrm{I}_{\mathrm{B}}{ }^{\mathrm{fl}}\right)$, the fluorescence intensity of the photoproducts increases sharply on going from solutions to a polymeric matrix at comparably equal changes of the photoinduced absorbance.

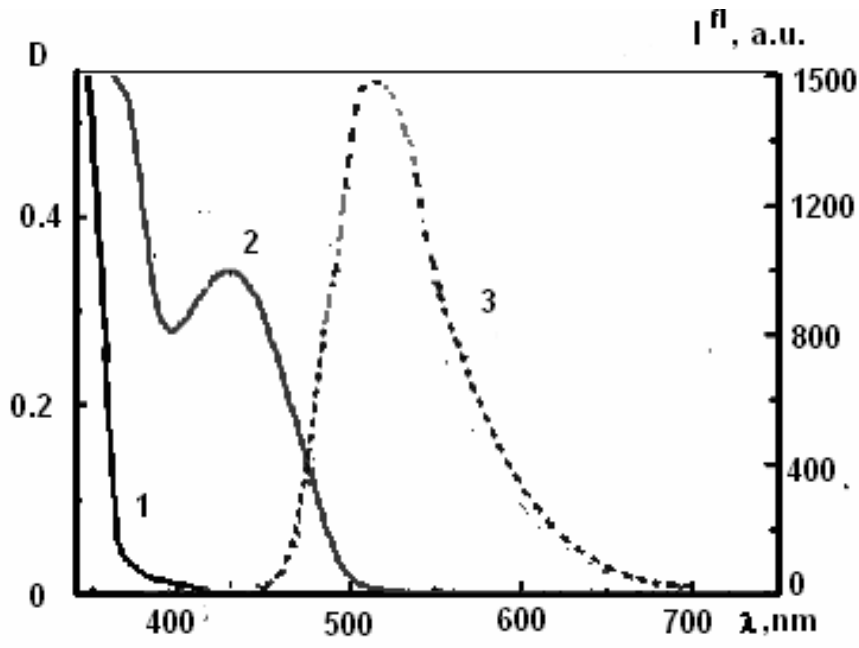

Figure 5. Absorption $(1,2)$ and fluorescence (3) spectra for the compound 10i in poly(methyl methacrylate) (PMMA) before (1), and after $(2,3)$ UV irradiation. The excitation irradiation of fluorescence is $440 \mathrm{~nm}$. 
Table 2. Spectral and kinetic characteristics of phototransformations of chromones in the polymeric matrices under UV light at $\lambda=300 \mathrm{~nm}$

\begin{tabular}{ccccccc}
\hline Compound & Polymer & $\begin{array}{c}\lambda_{\mathrm{A}}{ }^{\max }, \\
\mathrm{nm}\end{array}$ & $\begin{array}{c}\lambda_{\mathrm{B}}{ }^{\max }, \\
\mathrm{nm}\end{array}$ & $\begin{array}{c}\lambda_{\mathrm{B}}{ }^{\mathrm{fl}, \max } \\
\mathrm{nm}\end{array}$ & $\Delta \mathrm{D}_{\mathrm{B}}{ }^{\text {phot }}$ & $\Delta \mathrm{I}_{\mathrm{B}}{ }^{\mathrm{fl}}$, \\
$\mathbf{1 0 c}$ & PC & 310 & $350-500$ & 520 & 0.25 & 175 \\
& PS & $300-350$ & $350-500$ & 530 & 0.22 & 350 \\
& CAB & 300 & $350-490$ & 520 & 0.18 & 35 \\
& PVB & 310 & 445 & 525 & 0.06 & 450 \\
& PMMA & $310-440$ & 430 & 525 & 0.35 & $>2000$ \\
10d & PMMA & 270,315 & 380,440 & 530 & 0.35 & $>1000$ \\
\hline
\end{tabular}

Note: $\mathrm{PC}=$ polycarbonate; $\mathrm{PS}=-$ polystyrene $\mathrm{CAB}=$ cellulose acetate-butyrate; $\mathrm{PVB}=$ polyvinyl butyrate; PMMA = poly (methyl methacrylate).

Thus, the spectral and kinetic study of the synthesized chromones showed that the thiophenecontaining chromones manifest efficient irreversible photo-transformations in solutions, to form the photoluminescent photoproduct with appropriate photosensitivity and efficiency of fluorescence of the photoproducts. The introduction of chromones into the polymeric matrix provides a sharp increase in the intensity of photoinduced fluorescence, especially in PMMA.

\section{Experimental Section}

General Procedures. H NMR spectra were recorded on Bruker AC-200 (200 MHz) and WM$250(250 \mathrm{MHz})$ instruments in DMSO- $\mathrm{d}_{6}$ or $\mathrm{CDCl}_{3}$. Mass spectra were recorded on a Varian MAT CH-6 instrument with direct sample injection into the radiation source, with ionization energy $70 \mathrm{eV}$, and the controlling voltage $1.75 \mathrm{kV}$. Melting points were measured on a Boetius heating stage and were not corrected. TLC on Merck Silica gel 60 F254 UV-254 plates was used for analysis of all reaction mixtures and for monitoring the purity of all isolated products. RT denotes room temperature. The synthesized compounds $\mathbf{1 0}$ were dissolved in toluene (Aldrich) for analyzing the photometric data. The concentration of compounds in the solution was $C=2.10^{-}$ ${ }^{4} M$. A quartz cell of thickness $l=0.2 \mathrm{~cm}$ was used for spectroscopic and kinetic absorption measurements, which were carried out using a USB2000 fiber-optical spectrometer (Ocean Optics). Fluorescence spectra were measured using a CARY ECLIPSE (Varian) spectrofluorimeter with quartz cuvettes of thickness $l=1 \mathrm{~cm}$, and solutions with chromone concentration $C=4.10^{-5} \mathrm{M}$. Polymer films were prepared by dissolving the chromone $(0.5 \mathrm{mg})$ and a polymer binder $(100 \mathrm{mg})$ in methoxypropanol $(0.25 \mathrm{ml})$ with subsequent swelling, casting on the Dacron flexible support, and evaporation of solvent. UV irradiation from a DRSh-250 lamp, through an interference light filter transmitting irradiation with $\lambda=313 \mathrm{~nm}$ was used for the photochemical study of the synthesized compounds. 
General procedure for the acylation of 2-hydroxyacetophenones (6)

Freshly distilled anhydrous pyridine $(5 \mathrm{ml})$ was added to 2-hydroxyacetophenone or 2-hydroxy5 -methylacetophenone $(0.025 \mathrm{~mol})$ under cooling with iced water. Then the aromatic acid's acyl chloride $(0.030 \mathrm{~mol})$ was added dropwise at $<25{ }^{\circ} \mathrm{C}$. The mixture was then left to stand for $40-60$ min and poured into a $3 \%$ cooled solution of hydrochloric acid. The precipitate formed was filtered off, dried, and recrystallized from ethanol.

2-Acetylphenyl benzoate (6a). Yield $5.4 \mathrm{~g}$ (90\%), mp 87-88 ${ }^{\circ} \mathrm{C}(\mathrm{EtOH}) .{ }^{1} \mathrm{H} \mathrm{NMR}\left(\mathrm{CDCl}_{3}\right) \delta$ $8.23(2 \mathrm{H}, \mathrm{d}, J=7.5 \mathrm{~Hz}), 7.87(1 \mathrm{H}, \mathrm{d}, J=7.8 \mathrm{~Hz}), 7.72-7.50(4 \mathrm{H}, \mathrm{m}), 7.39(1 \mathrm{H}, \mathrm{m}) ; 7.25(1 \mathrm{H}, \mathrm{d}, J$ $=7.7 \mathrm{~Hz}), 2.57(3 \mathrm{H}, \mathrm{s}) . m / z$ 240. Anal. Calcd for $\mathrm{C}_{15} \mathrm{H}_{12} \mathrm{O}_{3}: \mathrm{C}, 74.99 ; \mathrm{H}, 5.03$. Found: C, 75.16; $\mathrm{H}, 4.98 \%$.

2-Acetylphenyl thiophene-2-carboxylate (6c). Yield $5.3 \mathrm{~g}$ in $(86 \%)$, mp $114{ }^{\circ} \mathrm{C}(\mathrm{EtOH}) .{ }^{1} \mathrm{H}$ $\operatorname{NMR}\left(\mathrm{CDCl}_{3}\right) \delta 8.05(1 \mathrm{H}, \mathrm{d}, J=3.2 \mathrm{~Hz}), 7.87(1 \mathrm{H}, \mathrm{m}), 7.70(1 \mathrm{H}, \mathrm{d}, J=4.5 \mathrm{~Hz}), 7.60(1 \mathrm{H}, \mathrm{m})$, $7.38(1 \mathrm{H}, \mathrm{m}), 7.17-7.20(2 \mathrm{H}, \mathrm{m}), 2.59(3 \mathrm{H}, \mathrm{s}) . \mathrm{m} / z$ 246. Anal. Calcd for $\mathrm{C}_{13} \mathrm{H}_{10} \mathrm{O}_{3} \mathrm{~S}, \mathrm{C}, 63.40 ; \mathrm{H}$, 4.09; S, 13.02. Found: C, 63.50; H, 3.98; S, 13.13\%.

2-Acetyl-4-methylphenyl thiophene-2-carboxylate (6d). Yield 5.46 g (84\%), m.p. 90-91 ${ }^{\circ} \mathrm{C}$ (EtOH). ${ }^{1} \mathrm{H}$ NMR $\left(\mathrm{CDCl}_{3}\right) \delta 8.0(1 \mathrm{H}, \mathrm{d}, J=3.6 \mathrm{~Hz}), 7.67(2 \mathrm{H}, \mathrm{m}) ; 7.37(1 \mathrm{H}, \mathrm{m}), 7.1-7.2(2 \mathrm{H}$, m), $2.55(3 \mathrm{H}, \mathrm{s}), 2.42(3 \mathrm{H}, \mathrm{s})$. MS $m / z(260)$. Anal. Calcd for $\mathrm{C}_{14} \mathrm{H}_{12} \mathrm{O}_{3} \mathrm{~S}: \mathrm{C}, 64.60 ; \mathrm{H}, 4.65 ; \mathrm{S}$; 12.32. Found: C, 64.50; H, 4.58; S, 12.45\%.

2-Acetylphenyl 5-methylthiophene-2-carboxylate (6e). Yield 5.59 g (86\%), m.p. 106-107 ${ }^{\circ} \mathrm{C}$ (EtOH). ${ }^{1} \mathrm{H}$ NMR $\left(\mathrm{CDCl}_{3}\right) \delta 7.94(1 \mathrm{H}, \mathrm{d}, J=9.2 \mathrm{~Hz}), 7.85(1 \mathrm{H}, \mathrm{d}, J=3.7 \mathrm{~Hz}), 7.68(1 \mathrm{H}, \mathrm{m})$, $7.35(1 \mathrm{H}, \mathrm{d}, J=8.1 \mathrm{~Hz}), 7.45(1 \mathrm{H}, \mathrm{m}), 7.04(1 \mathrm{H}, \mathrm{d}, J=3.7 \mathrm{~Hz}), 3.39(3 \mathrm{H}, \mathrm{s}), 2.60(3 \mathrm{H}, \mathrm{s}) . \mathrm{MS}$ $m / z$ 260. Anal. Calcd for $\mathrm{C}_{14} \mathrm{H}_{12} \mathrm{O}_{3} \mathrm{~S}$ : C, 64.60; H, 4.65; S, 12.32. Found: C, 64.78; H, 4.58; S, $12.37 \%$.

2-Acetyl-4-methylphenyl 5-methylthiophene-2-carboxylate (6f). Yield 5.49 g (80\%), m.p. 72 ${ }^{\circ} \mathrm{C}(\mathrm{EtOH}) .{ }^{1} \mathrm{H} \mathrm{NMR}\left(\mathrm{CDCl}_{3}\right) \delta 7.80(1 \mathrm{H}, \mathrm{d}, J=3.7 \mathrm{~Hz}), 7.63(1 \mathrm{H}, \mathrm{d}, J=1.7 \mathrm{~Hz}), 7.35(1 \mathrm{H}, \mathrm{m})$, $7.12(1 \mathrm{H}, \mathrm{d}, J=8.2 \mathrm{~Hz}), 6.85(1 \mathrm{H}, \mathrm{d}, J=0.7 \mathrm{~Hz}), 2.61(3 \mathrm{H}, \mathrm{s}), 2.56(3 \mathrm{H}, \mathrm{s}), 2.40(3 \mathrm{H}, \mathrm{s}) . \mathrm{MS}$ $m / z$ 274. Anal. Calcd for $\mathrm{C}_{15} \mathrm{H}_{14} \mathrm{O}_{3} \mathrm{~S}$ : C, 65.67; H, 5.14; S, 11.69. Found: C, 65.82; H, 5.07; S, $11.78 \%$.

2-Acetylphenyl furan-2-carboxylate (6h). Yield $4.60 \mathrm{~g}(80 \%)$, m.p. $=90-92{ }^{\circ} \mathrm{C}(\mathrm{EtOH}) .{ }^{1} \mathrm{H}$ $\operatorname{NMR}\left(\mathrm{CDCl}_{3}\right) \delta 7.87(1 \mathrm{H}, \mathrm{d}, J=7.3 \mathrm{~Hz}), 7.20(1 \mathrm{H}, \mathrm{s}), 7.42(1 \mathrm{H}, \mathrm{m}), 7.10(1 \mathrm{H}, \mathrm{m}), 7.42(2 \mathrm{H}$, m), $7.26(1 \mathrm{H}, \mathrm{d}, J=7.4 \mathrm{~Hz}), 6.63(1 \mathrm{H}, \mathrm{m}), 2.58(3 \mathrm{H}, \mathrm{s}) . \mathrm{MS} m / z$ 230. Anal. Calcd for $\mathrm{C}_{13} \mathrm{H}_{10} \mathrm{O}_{4}$ : C, 67.82; H, 4.38. Found: C, 67.69; H, 4.30\%.

2-Acetylphenyl 3-nitrobenzoate (6m). Yield $6.42 \mathrm{~g}(90 \%), \mathrm{m} . \mathrm{p} .=103-104{ }^{\circ} \mathrm{C}(\mathrm{EtOH}) .{ }^{1} \mathrm{H} \mathrm{NMR}$ $\left(\mathrm{CDCl}_{3}\right) \delta 8.23(2 \mathrm{H}, \mathrm{d}, J=7.5 \mathrm{~Hz}), 7.87(1 \mathrm{H}, \mathrm{d}, J=7.8 \mathrm{~Hz}), 7.72-7.50(4 \mathrm{H}, \mathrm{m}), 7.39(1 \mathrm{H}, \mathrm{m})$, $7.25(1 \mathrm{H}, \mathrm{d}, J=7.8 \mathrm{~Hz}), 2.57(3 \mathrm{H}, \mathrm{s})$. MS m/z 285. Anal. Calcd for $\mathrm{C}_{15} \mathrm{H}_{11} \mathrm{NO}_{5}$ : C, 63.16; $\mathrm{H}$, 3.89; N, 4.91. Found: C, 63.29; H, 3.78; N, 4.80\%.

\section{General Procedure for the Preparation of propane-1,3-dione derivatives (7)}

A solution of $o$-acyloxyacetophenone $(0.0125 \mathrm{~mol})$ in DMF $(10 \mathrm{ml})$ was added, under argon, during 10 min to a solution of $t$-BuOK $(2.8 \mathrm{~g})$ in DMF at RT. The mixture was kept for $1 \mathrm{~h}$ and 
then poured into an ice-cooled 3\% solution of hydrochloric acid. The product that precipitated was filtered off and dried in air, then recrystallized from ethanol or methanol.

1-(2-Hydroxyphenyl)-3-phenylpropane-1,3-dione (7a). Yield 2.49 g (83\%), m.p. $122{ }^{\circ} \mathrm{C}$ $(\mathrm{EtOH}) .{ }^{1} \mathrm{H}$ NMR $\left(\mathrm{CDCl}_{3}\right) \delta 15.55(1 \mathrm{H}, \mathrm{s}), 12.10(1 \mathrm{H}, \mathrm{s}), 7.95(2 \mathrm{H}, \mathrm{d}, J=6.6 \mathrm{~Hz}), 7.80(1 \mathrm{H}, \mathrm{d}$, $J=7.9 \mathrm{~Hz}), 7.40-7.70(4 \mathrm{H}, m), 6.80-7.10(3 \mathrm{H}, m)$. MS $m / z$ 240. Anal. Calcd for $\mathrm{C}_{15} \mathrm{H}_{12} \mathrm{O}_{3}$ : C, 74.99; H, 5.03. Found: C, 74.85; H, 4.96\%.

1-(2-Hydroxyphenyl)-3-(thiophen-2-yl)propane-1,3-dione (7c). Yield $2.06 \mathrm{~g}$ (67\%), m.p.= 90$92^{\circ} \mathrm{C}(\mathrm{EtOH}) .{ }^{1} \mathrm{H}$ NMR $\left(\mathrm{CDCl}_{3}\right) \delta 11.30(1 \mathrm{H}, \mathrm{s}), 11.00(1 \mathrm{H}, \mathrm{s}), 7.80-8.10(3 \mathrm{H}, \mathrm{m}), 7.50(1 \mathrm{H}, m)$, $7.3(1 \mathrm{H}, \mathrm{m}), 6.90-7.00(2 \mathrm{H}, m) 4.80(1 \mathrm{H}, \mathrm{s})$. MS $m / z$ 246. Anal. Calcd for $\mathrm{C}_{13} \mathrm{H}_{10} \mathrm{O}_{3} \mathrm{~S}: \mathrm{C}, 63.40$; H, 4.09; S, 13.02. Found: C, 63.50; H, 4.02; S, 13.13\%.

1-(2-Hydroxy-5-methylphenyl)-3-(thiophen-2-yl)propane-1,3-dione (7d). Yield $1.87 \mathrm{~g}$ (57.5\%), m.p. 84-86 ${ }^{\circ} \mathrm{C}(\mathrm{EtOH}) .{ }^{1} \mathrm{H}$ NMR $\left(\mathrm{CDCl}_{3}\right) \delta 15.75(1 \mathrm{H}, \mathrm{s}), 11.70(1 \mathrm{H}, \mathrm{s}), 7.80(1 \mathrm{H}$, m), 7.50-7.60 (2H, m), 7.20-7.35 (2H, m), $6.90 \mathrm{~d}(1 \mathrm{H}, J=8.5 \mathrm{~Hz}), 6.70(1 \mathrm{H}, \mathrm{m}), 4.45(1 \mathrm{H}, \mathrm{s})$, $2.36(3 \mathrm{H}, \mathrm{s}) . \mathrm{MS} m / z$ 260. Anal. Calcd for $\mathrm{C}_{14} \mathrm{H}_{12} \mathrm{O}_{3} \mathrm{~S}: \mathrm{C}, 64.60 ; \mathrm{H}, 4.65 ; \mathrm{S}, 12.32$. Found: $\mathrm{C}$, $64.45 ; \mathrm{H}, 4.57 ; \mathrm{S}, 12.47 \%$.

1-(2-Hydroxyphenyl)-3-(5-methylthiophen-2-yl)propane-1,3-dione (7e). Yield $1.69 \mathrm{~g} \mathrm{(52 \% ),}$ m.p. $=81{ }^{\circ} \mathrm{C}(\mathrm{EtOH}) .{ }^{1} \mathrm{H}$ NMR $\left(\mathrm{CDCl}_{3}\right) \delta 11.35(1 \mathrm{H}, \mathrm{s}), 10.93(1 \mathrm{H}, \mathrm{s}), 7.85(2 \mathrm{H}, \mathrm{m}), 7.45(1 \mathrm{H}$, m), $6.99(3 \mathrm{H}, \mathrm{m}), 4.60(1 \mathrm{H}, \mathrm{s}), 2.5(3 \mathrm{H}, \mathrm{s})$. MS $m / z(260)$. Anal. Calcd for $\mathrm{C}_{14} \mathrm{H}_{12} \mathrm{O}_{3} \mathrm{~S}: \mathrm{C}, 64.60$; $\mathrm{H}, 4.65 ; \mathrm{S}, 12.32$. Found: C, 64.75; H, 4.61; S, 12.26\%.

1-(2-Hydroxy-5-methylphenyl)-3-(5-methylthiophen-2-yl)propane-1,3-dione (7f). Yield 2.16 g (63\%), m.p. $115-117^{\circ} \mathrm{C}(\mathrm{EtOH}) .{ }^{1} \mathrm{H}$ NMR $\left(\mathrm{CDCl}_{3}\right) \delta 15.8(1 \mathrm{H}, \mathrm{s}), 11.8(1 \mathrm{H}, \mathrm{s}), 7.7(1 \mathrm{H}, \mathrm{m}), 7.3$ $(1 \mathrm{H}, \mathrm{m}), 6.9(2 \mathrm{H}, \mathrm{m}), 6.6(1 \mathrm{H}, \mathrm{m}), 4.5(1 \mathrm{H}, \mathrm{s}), 2.6(3 \mathrm{H}, \mathrm{s}), 2.4(3 \mathrm{H}, \mathrm{s})$. MS m/z $(274)$. Anal. Calcd for $\mathrm{C}_{15} \mathrm{H}_{14} \mathrm{O}_{3} \mathrm{~S}: \mathrm{C}, 65.67 ; \mathrm{H}, 5.14 ; \mathrm{S}, 11.69$. Found: C, 65.55; H, 5.10; S, 11.85\%.

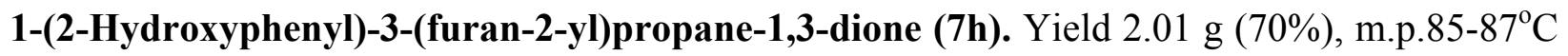
$(\mathrm{EtOH}) .{ }^{1} \mathrm{H}$ NMR $\left(\mathrm{CDCl}_{3}\right) \delta 15.12(1 \mathrm{H}, \mathrm{s}), 12.11(1 \mathrm{H}, \mathrm{s}), 7.80(1 \mathrm{H}, \mathrm{d}, J=8.1 \mathrm{~Hz}), 7.65(1 \mathrm{H}, \mathrm{m})$, $7.50(1 \mathrm{H}, \mathrm{m}), 7.19(1 \mathrm{H}, \mathrm{d}, J=3.5 \mathrm{~Hz}), 6.89-7.02(2 \mathrm{H}, \mathrm{m}), 6.79(1 \mathrm{H}, \mathrm{s}), 6.61(1 \mathrm{H}, \mathrm{m}) . \mathrm{MS} m / z$ 230. Anal. Calcd for $\mathrm{C}_{13} \mathrm{H}_{10} \mathrm{O}_{4}$ : C, 67.82; H, 4.38. Found: $\mathrm{C}, 67.68 ; \mathrm{H}, 4.31 \%$.

1-(2-Hydroxyphenyl)-3-(3-nitrophenyl)propane-1,3-dione (7m). Finely dispersed potassium hydroxide (1.2 equiv.) was added in small portions to 1 equiv. of $o$-acyloxy-acetophenone in a minimum amount of pyridine with cooling below $10{ }^{\circ} \mathrm{C}$, and with vigorous stirring under argon. The solution darkened and after some time an ochre-yellow precipitate formed. After $20 \mathrm{~min}$, cooling was stopped, and the mixture was stirred at RT. After the end of the reaction (TLC monitoring), the mixture was poured into ice-cold water, and acidified with hydrochloric acid. The product was filtered off and recrystallized from ethanol (in the case of a crystalline precipitate) or, in the case of an oil, was extracted with methylene chloride and filtered through a silica gel layer, and the resulting solution concentrated on a rotary evaporator and washed with ice-cold methanol, rejecting the washings. The crystalline precipitate was recrystallized from ethanol. Yield 33\%; m.p. $155^{\circ} \mathrm{C} . \mathrm{NMR}\left(\mathrm{CDCl}_{3}\right) \delta 15.0(1 \mathrm{H}, \mathrm{s}), 11.90(1 \mathrm{H}, \mathrm{s}), 8.77(1 \mathrm{H}, \mathrm{s}), 8.40$ 
$(1 \mathrm{H}, \mathrm{d}, J=8.2), 8.30(1 \mathrm{H}, \mathrm{d}, J=7.9 \mathrm{~Hz}), 7.85(1 \mathrm{H}, \mathrm{d}, J=7.9 \mathrm{~Hz}), 7.70(1 \mathrm{H}, \mathrm{m}), 7.50(1 \mathrm{H}, \mathrm{m})$, $6.92(1 \mathrm{H}, \mathrm{s})$. MS m/z (285). Anal. Calcd for $\mathrm{C}_{15} \mathrm{H}_{11} \mathrm{NO}_{5}$ : C, 63.16; H, 3.89; N, 4.91. Found: $\mathrm{C}$, $63.05 ; \mathrm{H}, 3.79 ; \mathrm{N}, 4.78 \%$.

Reaction of propane-1,3-dione derivatives with aldehydes to form compounds (9). General procedure

A solution of the 2-hydroxyphenyl-1,3-diketone (7) $(0.005 \mathrm{~mol})$, furfurol derivative $(0.0055$ $\mathrm{mol}$ ), and a drop of piperidine in ethanol $\left(15 \mathrm{ml}\right.$ ) was stirred with cooling (from -10 to $15{ }^{\circ} \mathrm{C}$ ) for 3-6 h. At first the insoluble diketone is slowly transferred into the solution. At the end of the reaction, the precipitated product was filtered off, washed with ice-cold ethanol, recrystallized from ethanol or methanol, and dried in air.

3-Benzoyl-2-(furan-2-yl)chroman-4-one (9a). Yield $1.27 \mathrm{~g}(80 \%)$, m.p. $=167-169{ }^{\circ} \mathrm{C}(\mathrm{EtOH})$. ${ }^{1} \mathrm{H}$ NMR $\left(\mathrm{CDCl}_{3}\right) \delta 16.65(1 \mathrm{H}, \mathrm{s}), 7.93(1 \mathrm{H}, \mathrm{d}, J=7.7 \mathrm{~Hz}), 7.33-7.60(7 \mathrm{H}, \mathrm{m}), 7.05(1 \mathrm{H}, \mathrm{m})$, $6.90(1 \mathrm{H}, \mathrm{d}, J=8.2 \mathrm{~Hz}), 6.25(2 \mathrm{H}, \mathrm{d}, J=5.4 \mathrm{~Hz})$. MS $m / z$ 318. Anal. Calcd for, $\mathrm{C}_{20} \mathrm{H}_{14} \mathrm{O}_{4}$ : C, 75.46; H, 4.43. Found: C, 75.30; H, 4.39\%.

3-Benzoyl-2-(5-methylfuran-2-yl)chroman-4-one (9b). Yield 1.33 g (80\%), m.p. $=143-145{ }^{\circ} \mathrm{C}$ (EtOH). ${ }^{1} \mathrm{H}$ NMR $\left(\mathrm{CDCl}_{3}\right) \delta 17.05(1 \mathrm{H}, \mathrm{s}), 7.90(1 \mathrm{H}, \mathrm{m}), 7.70(1 \mathrm{H}, \mathrm{m}), 6.9-7.35(5 \mathrm{H}, \mathrm{m}), 6.60$ $(1 \mathrm{H}, \mathrm{m}), 6.35(1 \mathrm{H}, \mathrm{m}), 5.90(1 \mathrm{H}, \mathrm{m}), 5.12(1 \mathrm{H}, \mathrm{m}, J=11.4 \mathrm{~Hz}), 2.25(3 \mathrm{H}, \mathrm{s}) . \mathrm{MS} m / z(332)$. Anal. Calcd for $\mathrm{C}_{21} \mathrm{H}_{16} \mathrm{O}_{4}$ : C, 75.89; H, 4.85. Found: C, 76.01; H, 4.95\%.

2-(Furan-2-yl)-3-(thiophene-2-carbonyl)chroman-4-one (9c). Yield $0.78 \mathrm{~g} \mathrm{(48 \% ),} \mathrm{m.p.=} \mathrm{128-}$ $130{ }^{\circ} \mathrm{C}(\mathrm{EtOH}) .{ }^{1} \mathrm{H}$ NMR $\left(\mathrm{CDCl}_{3}\right) \delta 8.23(1 \mathrm{H}, \mathrm{d}, J=3.7 \mathrm{~Hz}), 8.06(1 \mathrm{H}, \mathrm{m}), 7.82(1 \mathrm{H}, \mathrm{d}, J=7.1$ $\mathrm{Hz}), 7.66(2 \mathrm{H}, \mathrm{m}), 7.29(1 \mathrm{H}, \mathrm{m}), 7.15(2 \mathrm{H}, \mathrm{m}), 6.59(1 \mathrm{H}, \mathrm{d}, J=3.2 \mathrm{~Hz}), 6.40(1 \mathrm{H}, \mathrm{m}), 5.97(1 \mathrm{H}$, $\mathrm{d}, J=11.8 \mathrm{~Hz}), 5.73(1 \mathrm{H}, \mathrm{d}, J=8.7 \mathrm{~Hz}) . \mathrm{MS} m / z$ 324. Anal. Calcd for $\mathrm{C}_{18} \mathrm{H}_{12} \mathrm{O}_{4} \mathrm{~S}: \mathrm{C}, 66.65 ; \mathrm{H}$, 3.73; S, 9.89. Found: C, 66.52; H, 3.64; S, 10.04\%.

2-(Furan-2-yl)-6-methyl-3-(thiophene-2-carbonyl)chroman-4-one (9d). Yield 1.39 g (82\%), m.p. $=150-152{ }^{\circ} \mathrm{C}(\mathrm{EtOH}) .{ }^{1} \mathrm{H}$ NMR $\left(\mathrm{CDCl}_{3}\right) \delta 17.3(1 \mathrm{H}, \mathrm{s}), 7.70(1 \mathrm{H}, \mathrm{s}), 7.60(1 \mathrm{H}, \mathrm{d}, J=4.9$ $\mathrm{Hz}), 7.48(1 \mathrm{H}, \mathrm{s}), 7.22(2 \mathrm{H}, \mathrm{d}, J=3.9 \mathrm{~Hz}), 7.10(1 \mathrm{H}, \mathrm{m}), 6.80(1 \mathrm{H}, \mathrm{d}, J=7.4 \mathrm{~Hz}), 6.60(1 \mathrm{H}, \mathrm{s})$; $6.34(1 \mathrm{H}, \mathrm{d}, J=3.1 \mathrm{~Hz}), 6.25(1 \mathrm{H}, \mathrm{d}, J=1.5 \mathrm{~Hz}), 2.30(3 \mathrm{H}, \mathrm{s})$. MS $m / z$ 338. Anal. Calcd for $\mathrm{C}_{19} \mathrm{H}_{14} \mathrm{O}_{4} \mathrm{~S}$ : C, 67.44; H, 4.17; S, 9.48. Found: C, 67.60; H, 4.27; S, 9.40\%.

2-(Furan-2-yl)-3-(5-methylthiophene-2-carbonyl)chroman-4-one (9e). Yield 1.42 g (84\%), m.p. $=148-149{ }^{\circ} \mathrm{C}(\mathrm{EtOH}) .{ }^{1} \mathrm{H}$ NMR $\left(\mathrm{CDCl}_{3}\right) \delta 17.3(1 \mathrm{H}, \mathrm{s}), 7.90(1 \mathrm{H}, \mathrm{d}, J=8.0 \mathrm{~Hz}), 7.35-7.45$ $(2 \mathrm{H}, \mathrm{m}), 7.05(2 \mathrm{H}, \mathrm{m}), 6.90(1 \mathrm{H}, \mathrm{m}), 6.75(1 \mathrm{H}, \mathrm{d}, J=3.5 \mathrm{~Hz}), 6.62(1 \mathrm{H}, \mathrm{s}), 6.30(1 \mathrm{H}, \mathrm{d}), 2.52$ (3H, s). MS m/z 338. Anal. Calcd for $\mathrm{C}_{19} \mathrm{H}_{14} \mathrm{O}_{4} \mathrm{~S}$ : C, 67.44; H, 4.17; S, 9.48. Found: C, 67.31; H, 4.10; S, 9.59\%.

2-(Furan-2-yl)-6-methyl-3-(5-methylthiophene-2-carbonyl)chroman-4-one (9f). Yield $1.18 \mathrm{~g}$ (67\%), m.p. $=146-147^{\circ} \mathrm{C}(\mathrm{EtOH}) .{ }^{1} \mathrm{H} \mathrm{NMR}\left(\mathrm{CDCl}_{3}\right) \delta 17.40(1 \mathrm{H}, \mathrm{s}), 7.70(1 \mathrm{H}, \mathrm{m}), 7.35(1 \mathrm{H}, \mathrm{m})$, 6.7-7.3 (5H, m), $6.46(1 \mathrm{H}, \mathrm{d}, J=3.2 \mathrm{~Hz}), 6.26(1 \mathrm{H}, \mathrm{d}), 2.56(3 \mathrm{H}, \mathrm{s}) 2.31(3 \mathrm{H}, \mathrm{s}) . \mathrm{MS} \mathrm{m} / z 352$. Anal. Calcd for $\mathrm{C}_{20} \mathrm{H}_{16} \mathrm{O}_{4} \mathrm{~S}$ : C, 68.17; H, 4.58; S, 9.10. Found: C, 68.08; H, 4.50; S, 9.28\%. 
2-(5-Methylfuran-2-yl)-3-(thiophene-2-carbonyl)chroman-4-one (9g). Yield $0.727 \mathrm{~g}$ (43\%), m.p. $=122-124{ }^{\circ} \mathrm{C}(\mathrm{EtOH}) .{ }^{1} \mathrm{H} \mathrm{NMR}\left(\mathrm{CDCl}_{3}\right) \delta 8.5-8.00(3 \mathrm{H} \mathrm{m}), 7.00-7.30(4 \mathrm{H}, \mathrm{m}), 6.35(1 \mathrm{H}$, $\mathrm{m}), 5.58-6.00(2 \mathrm{H}, \mathrm{m}), 5.10(1 \mathrm{H}, \mathrm{d}, J=3.3 \mathrm{~Hz}), 2.3(3 \mathrm{H} \mathrm{s}) . \mathrm{MS} m / z$ 338. Anal. Calcd for $\mathrm{C}_{19} \mathrm{H}_{14} \mathrm{O}_{4} \mathrm{~S}: \mathrm{C}, 67.44 ; \mathrm{H}, 4.17$; S, 9.48. Found: C, 67.40; H, 4.12; S, 9.65\%.

3-(Furan-2-carbonyl)-2-(furan-2-yl)chroman-4-one (9h). Yield $1.05 \mathrm{~g}(68 \%), \mathrm{m} . \mathrm{p} .=176{ }^{\circ} \mathrm{C}$ (EtOH). ${ }^{1} \mathrm{H}$ NMR $\left(\mathrm{CDCl}_{3}\right) \delta 17.18(1 \mathrm{H}, \mathrm{s}), 7.91(1 \mathrm{H}, \mathrm{m}), 7.60(1 \mathrm{H}, \mathrm{m}), 7.40(1 \mathrm{H}, \mathrm{m}), 7.30(1 \mathrm{H}$, $\mathrm{m}), 7.19(1 \mathrm{H}, \mathrm{m}), 7.00-7.10(2 \mathrm{H}, \mathrm{m}), 6.56(1 \mathrm{H}, \mathrm{s}), 6.20(2 \mathrm{H}, \mathrm{m})$. MS $m / z$ 308. Anal. Calcd for $\mathrm{C}_{18} \mathrm{H}_{12} \mathrm{O}_{5}$ : C, 70.13; H, 3.92. Found: C, 70.02; H, 3.84\%.

3-(Furan-3-carbonyl)-2-(5-methylfuran-2-yl)chroman-4-one (9i). Yield $1.29 \mathrm{~g}$ (80\%) yield, m.p. $=168-169{ }^{\circ} \mathrm{C}(\mathrm{EtOH}) .{ }^{1} \mathrm{H} \mathrm{NMR}\left(\mathrm{CDCl}_{3}\right) \delta 7.95(3 \mathrm{H}, \mathrm{m}), 7.50(3 \mathrm{H}, \mathrm{m}), 7.10(2 \mathrm{H}, \mathrm{m}), 6.30$ $(1 \mathrm{H}, \mathrm{m}), 5.90(1 \mathrm{H}, \mathrm{m}), 5.33(1 \mathrm{H}, \mathrm{m}), 2.20(3 \mathrm{H}, \mathrm{s})$. MS $m / z$ 322. Anal. Calcd for $\mathrm{C}_{19} \mathrm{H}_{14} \mathrm{O}_{5}$ : C, 70.80; H, 4.38. Found: C, 70.68; H, 4.29\%.

3-Benzoyl-2-(5-nitrofuran-2-yl)chroman-4-one (9j). Yield $0.67 \mathrm{~g}(37 \%)$, m.p. $=140-142{ }^{\circ} \mathrm{C}$ (EtOH). ${ }^{1} \mathrm{H}$ NMR $\left(\mathrm{CDCl}_{3}\right) \delta 16.58(1 \mathrm{H}, \mathrm{s}), 7.93(1 \mathrm{H}, \mathrm{d}, J=7.8 \mathrm{~Hz}), 7.45-7.55(6 \mathrm{H}, \mathrm{m}), 7.13$ $(2 \mathrm{H}, \mathrm{m}), 6.98(1 \mathrm{H}, \mathrm{d}, J=8.3 \mathrm{~Hz}), 6.50(1 \mathrm{H}, \mathrm{d}, J=3.6 \mathrm{~Hz}), 6.30(1 \mathrm{H}, \mathrm{s}) . \mathrm{MS} m / z$ 363. Anal. Calcd for $\mathrm{C}_{20} \mathrm{H}_{13} \mathrm{NO}_{6}$ : C, 66.12; H, 3.61; N, 3.86. Found: C, 66.00; H, 3.56; N, 3.75\%.

3-Benzoyl-2-(thiophen-2-yl)chroman-4-one (9k). Yield 1.08 g (65\%), m.p.= 123-124 ${ }^{\circ} \mathrm{C}$ $(\mathrm{EtOH}) .{ }^{1} \mathrm{H}$ NMR $\left(\mathrm{CDCl}_{3}\right) \delta 16.6(1 \mathrm{H}, \mathrm{s}), 7.90(1 \mathrm{H}, \mathrm{d}, J=7.3 \mathrm{~Hz}), 7.32-7.55(6 \mathrm{H}, \mathrm{m}), 7.25(1 \mathrm{H}$, m), $7.10(2 \mathrm{H}, \mathrm{m}), 6.90(2 \mathrm{H}, \mathrm{m}), 6.45(1 \mathrm{H}, \mathrm{s})$. MS m/z 334. Anal. Calcd for $\mathrm{C}_{20} \mathrm{H}_{14} \mathrm{O}_{3} \mathrm{~S}: \mathrm{C}, 71.84$; H, 4.22; S, 9.59. Found: C, 71.70; H, 4.05; S, 9.75\%.

2-(5-Methylfuran-2-yl)-3-(5-methylthiophene-2-carbonyl)chroman-4-one (9I). Yield $1.44 \mathrm{~g}$ (82\%), m.p. $=138-140{ }^{\circ} \mathrm{C}(\mathrm{EtOH}) .{ }^{1} \mathrm{H} \mathrm{NMR}\left(\mathrm{CDCl}_{3}\right) \delta 17.30(1 \mathrm{H}, \mathrm{s}), 7.90(1 \mathrm{H}, \mathrm{d}, J=7.7 \mathrm{~Hz})$, $7.40(2 \mathrm{H}, \mathrm{m}), 7.05(2 \mathrm{H}, \mathrm{m}), 6,9(1 \mathrm{H}, \mathrm{d}, J=8.3 \mathrm{~Hz}), 6.57(1 \mathrm{H}, \mathrm{s}), 6.20(1 \mathrm{H}, \mathrm{d}, J=2.8 \mathrm{~Hz}), 5.80$ $(1 \mathrm{H}, \mathrm{s}), 2.52(3 \mathrm{H} \mathrm{s}), 2.30(3 \mathrm{H}, \mathrm{s})$. MS m/z (352). Anal. Calcd for, $\mathrm{C}_{20} \mathrm{H}_{16} \mathrm{O}_{4} \mathrm{~S}: \mathrm{C}, 68.17 ; \mathrm{H}, 4.58$; S, 9.10. Found: C, 68.03; H, 4.48; S, 9.22\%.

2-(Furan-2-yl)-3-(4-nitrobenzoyl)chroman-4-one (9m). Yield 1.14 g (63\%), m.p.=112-115 ${ }^{\circ} \mathrm{C}$ $(\mathrm{EtOH}) .{ }^{1} \mathrm{H}$ NMR $\left(\mathrm{CDCl}_{3}\right) \delta 16.51(1 \mathrm{H}, \mathrm{s}), 8.30(2 \mathrm{H}, \mathrm{m}), 7.95(1 \mathrm{H}, \mathrm{m}), 7.75(1 \mathrm{H}, \mathrm{m}), 7.60(1 \mathrm{H}$, m), $7.43(2 \mathrm{H}, \mathrm{m}), 7.10(1 \mathrm{H}, \mathrm{m}), 6.9(1 \mathrm{H}, \mathrm{m}), 6.31(2 \mathrm{H}, \mathrm{m}), 6.15(1 \mathrm{H}, \mathrm{s}) . \mathrm{MS} \mathrm{m} / z(363)$. Anal. Calcd for $\mathrm{C}_{20} \mathrm{H}_{13} \mathrm{NO}_{6}$ : C, 66.12; H, 3.61; N, 3.86. Found: C, 66.25; H, 3.51; N, 3.71\%.

\section{General Procedure for the synthesis of compounds (10)}

A mixture of the aldol condensation product 8 or 9 (0.001 mol), selenium dioxide $(220 \mathrm{mg})$, and dioxane $(10 \mathrm{ml})$ was refluxed for 2-6 $\mathrm{h}$ (TLC monitoring) until the initial product disappeared. The solvent was distilled off on a rotary evaporator, and the residue was dissolved in methylene chloride, filtered off from metallic selenium and unreacted selenium dioxide, and passed through a silica gel layer. The resulting transparent light solution was concentrated on a rotary evaporator and the residue was washed with ethanol.

2-(Furan-2-yl)-3-benzoyl-4H-chromen-4-one (10a). Yield $0.253 \mathrm{~g}(80 \%)$, m.p. $=214^{\circ} \mathrm{C}(\mathrm{EtOH})$. ${ }^{1} \mathrm{H}$ NMR $\left(\mathrm{CDCl}_{3}\right) \delta 8.05(1 \mathrm{H}, \mathrm{m}), 7.99(2 \mathrm{H}, \mathrm{m}), 7.90(1 \mathrm{H}, \mathrm{m}), 7.80(2 \mathrm{H}, \mathrm{m}), 7.65(1 \mathrm{H}, \mathrm{m}), 7.54$ 
$(3 \mathrm{H}, \mathrm{m}), 7.35(1 \mathrm{H}, \mathrm{m}), 6.72(1 \mathrm{H}, \mathrm{m}) . \mathrm{MS} \mathrm{m} / z$ 316. Anal. Calcd for $\mathrm{C}_{20} \mathrm{H}_{12} \mathrm{O}_{4}: \mathrm{C}, 75.94 ; \mathrm{H}, 3$. Found: C, 75.83; H, 3.77\%.

3-Benzoyl-2-(5-methylfuran-2-yl)-4H-chromen-4-one (10b). Yield 0.165 g (50\%), m.p.=177$179^{\circ} \mathrm{C}(\mathrm{EtOH}) .{ }^{1} \mathrm{H} \mathrm{NMR}\left(\mathrm{CDCl}_{3}\right) \delta 8.20(1 \mathrm{H}, \mathrm{d}, J=7.1 \mathrm{~Hz}), 8.00(2 \mathrm{H}, \mathrm{d}, J=7.0 \mathrm{~Hz}), 7.70(1 \mathrm{H}$, m), $7.55(3 \mathrm{H}, \mathrm{m}), 7.45(2 \mathrm{H}, \mathrm{m}), 7.05(1 \mathrm{H}, \mathrm{m}), 6.10(1 \mathrm{H}, \mathrm{m}), 2.14(3 \mathrm{H}, \mathrm{m}) . \mathrm{MS} \mathrm{m} / z$ 330, 316, 301. Anal. Calcd for $\mathrm{C}_{21} \mathrm{H}_{14} \mathrm{O}_{4}$ : C, 76.36; H, 4.27. Found: C, 76.25; H, 4.19\%.

2-( Furan-2-yl)-3-(thiophene-2-carbonyl)-4H-chromen-4-one (10c). Yield 0.221 g (67\%), m.p. $=217-218^{\circ} \mathrm{C}(\mathrm{EtOH}) .{ }^{1} \mathrm{H}$ NMR $\left(\mathrm{CDCl}_{3}\right) \delta 8.06(2 \mathrm{H}, \mathrm{m}), 7.90(2 \mathrm{H}, \mathrm{m}), 7.80(2 \mathrm{H}, \mathrm{m}), 7.56$ $(1 \mathrm{H}, \mathrm{m}), 7.35(1 \mathrm{H}, \mathrm{m}), 7.17(1 \mathrm{H}, \mathrm{m}), 6.25(1 \mathrm{H}, \mathrm{m}) . \mathrm{MS} m / z$ 322, 309, 294. Anal. Calcd for $\mathrm{C}_{18} \mathrm{H}_{10} \mathrm{O}_{4} \mathrm{~S}$ : C, 67.07; H, 3.13; S, 9.95. Found: C, 67.19; H, 3.00; S, 10.02\%.

2-(Furan-2-yl)-6-Methyl-3-(thiophene-2-carbonyl)-4H-chromen-4-one (10d). Yield $0.279 \mathrm{~g}$ (83\%), m.p. $=187^{\circ} \mathrm{C}(\mathrm{EtOH}) .{ }^{1} \mathrm{H} \mathrm{NMR}\left(\mathrm{CDCl}_{3}\right) \delta 8.00(1 \mathrm{H}, \mathrm{s}), 7.69(1 \mathrm{H}, \mathrm{m}), 7.60(1 \mathrm{H}, \mathrm{m}), 7.53$ $(1 \mathrm{H}, \mathrm{d}, J=2.0 \mathrm{~Hz}), 7.49(2 \mathrm{H}, \mathrm{m}), 7.18(1 \mathrm{H}, \mathrm{d}, J=3.6 \mathrm{~Hz}), 7.03(1 \mathrm{H}, \mathrm{m}), 6.53(1 \mathrm{H}, \mathrm{m}), 2.45(3 \mathrm{H}$, s). MS m/z 336, 308. Anal. Calcd for $\mathrm{C}_{19} \mathrm{H}_{12} \mathrm{O}_{4} \mathrm{~S}: \mathrm{C}, 67.85 ; \mathrm{H}, 3.60 ; \mathrm{S}, 9.53$. Found: $\mathrm{C}, 67.73$; $\mathrm{H}$, $3.75 ; \mathrm{S}, 9.52 \%$.

2-(Furan-2-yl)-3-(5-Methylthiophene-2-carbonyl)-4H-chromen-4-one (10e). Yield $0.189 \mathrm{~g}$ (56\%), m.p. $=178-180^{\circ} \mathrm{C}(\mathrm{EtOH}) .{ }^{1} \mathrm{H}$ NMR $\left(\mathrm{CDCl}_{3}\right) \delta 8.22(1 \mathrm{H}, \mathrm{m}), 7.75(1 \mathrm{H}, \mathrm{m}), 7.52(2 \mathrm{H}, \mathrm{m})$, $7.45(2 \mathrm{H}, \mathrm{m}), 7.16(1 \mathrm{H}, \mathrm{d}, J=3.6 \mathrm{~Hz}), 6.75(1 \mathrm{H}, \mathrm{d}, J=3.7 \mathrm{~Hz}), 6.54(1 \mathrm{H}, \mathrm{m}), 2.52(3 \mathrm{H}, \mathrm{s}) . \mathrm{MS}$ $m / z(336,308)$. Anal. Calcd for $\mathrm{C}_{19} \mathrm{H}_{12} \mathrm{O}_{4} \mathrm{~S}$ : C, 67.85; H, 3.60; S, 9.53.Found: C, 67.99; H, 3.50; S, $9.39 \%$.

2-(Furan-2-yl)-6-methyl-3-(5-methylthiophene-2-carbonyl)-4H-chromen-4-one (10f). Yield of $10 f 0.208 \mathrm{~g}(59 \%)$, m.p. $=174-175^{\circ} \mathrm{C}(\mathrm{EtOH}) .{ }^{1} \mathrm{H} \mathrm{NMR}\left(\mathrm{CDCl}_{3}\right) \delta 8.00(1 \mathrm{H}, \mathrm{s}), 7.43-7.55(4 \mathrm{H}$, m), $7.15(1 \mathrm{H}, \mathrm{d}, J=3.6 \mathrm{~Hz}), 6.73(1 \mathrm{H}, \mathrm{d}, J=3.6 \mathrm{~Hz}), 6.53(1 \mathrm{H}, \mathrm{m}), 2.55(3 \mathrm{H}, \mathrm{s}), 2.45(3 \mathrm{H}, \mathrm{s})$. MS $m / z$ 350, 322. Anal. Calcd for $\mathrm{C}_{20} \mathrm{H}_{14} \mathrm{O}_{4} \mathrm{~S}$ : C, 68.56; H, 4.03; S, 9.15. Found: C, 68.45; $\mathrm{H}$, 4.16; S, 9.33\%.

2-(5-Methylfuran-2-yl)-3-(thiophene-2-carbonyl)-4H-chromen-4-one (10g). Yield $0.237 \mathrm{~g}$ (70\%), m.p. $=192-193{ }^{\circ} \mathrm{C}(\mathrm{EtOH}) .{ }^{1} \mathrm{H} \mathrm{NMR}\left(\mathrm{CDCl}_{3}\right) \delta 8.22(1 \mathrm{H}, \mathrm{d}, J=7.9 \mathrm{~Hz}), 7.66-7.77(2 \mathrm{H}$, m), 7.40-7.60 (3H, m), $7.08(2 \mathrm{H}, \mathrm{m}), 6.13(1 \mathrm{H}, \mathrm{d}, J=2.9 \mathrm{~Hz}), 2.20(3 \mathrm{H}, \mathrm{s})$. MS m/z 336. Anal. Calcd for $\mathrm{C}_{19} \mathrm{H}_{12} \mathrm{O}_{4} \mathrm{~S}$ : C, 67.85; H, 3.60; S, 9.53. Found: C, 67.75; H, 3.50; S, 9.70\%.

3-(Furancarbonyl)-2-(furan-2-yl)-4H-chromen-4-one $\quad \mathbf{( 1 0 h )}$ Yield $\quad 0.214 \quad \mathrm{~g} \quad(70 \%)$, m.p. $=216^{\circ} \mathrm{C}(\mathrm{EtOH}) .{ }^{1} \mathrm{H} \mathrm{NMR}\left(\mathrm{CDCl}_{3}\right) \delta 8.23(1 \mathrm{H}, \mathrm{m}), 7.73(1 \mathrm{H}, \mathrm{m}), 7.40-7.60(4 \mathrm{H}, \mathrm{m}), 7.20$ $(2 \mathrm{H}, \mathrm{d}, J=3.2 \mathrm{~Hz}), 6.54(2 \mathrm{H}, \mathrm{m})$. MS $m / z$ 306. Anal. Calcd for $\mathrm{C}_{18} \mathrm{H}_{10} \mathrm{O}_{5}: \mathrm{C}, 70.59 ; \mathrm{H}$, 3.29.Found: C, 70.48; H, 3.22\%.

2-(5- Methylfuran-2-yl)-3-(furan-2-carbonyl)-4H-chromen-4-one (10i). Yield 0.256 g (80\%), m.p. $=194-196^{\circ} \mathrm{C}(\mathrm{EtOH}) .{ }^{1} \mathrm{H}$ NMR $\left(\mathrm{CDCl}_{3}\right) \delta 8.22(1 \mathrm{H}, \mathrm{m}), 7.22(1 \mathrm{H}, \mathrm{m}), 7.60(1 \mathrm{H}, \mathrm{d}, J=0.9$ $H z), 7.40-7.55(2 \mathrm{H}, \mathrm{m}), 7.19(1 \mathrm{H}, \mathrm{d}, J=3.6 \mathrm{~Hz}) ; 7.10(1 \mathrm{H}, \mathrm{d}, J=3.5 \mathrm{~Hz}), 6.55(1 \mathrm{H}, \mathrm{m}), 6.19$ $(1 \mathrm{H}, \mathrm{d}, J=3.4 \mathrm{~Hz}), 2.20(3 \mathrm{H}, \mathrm{s}) . \mathrm{MS} m / z(320,305,292,278)$. Anal. Calcd for $\mathrm{C}_{19} \mathrm{H}_{12} \mathrm{O}_{5}$ : C, 71.25; H, 3.78. Found: C, 71.10; H, 3.72\%.

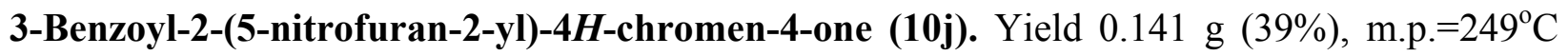
(EtOH). ${ }^{1} \mathrm{H}$ NMR $\left(\mathrm{CDCl}_{3}\right) \delta 8.27(1 \mathrm{H}, \mathrm{d}, J=7.2 \mathrm{~Hz}), 8.02(2 \mathrm{H}, \mathrm{d}, J=7.3 \mathrm{~Hz}), 7.33(1 \mathrm{H}, \mathrm{m})$, 
7.43-7.65 (5H, m), $7.32(1 \mathrm{H}, \mathrm{d}, J=3.8 \mathrm{~Hz}), 7.22(1 \mathrm{H}, \mathrm{d}, J=3.7 \mathrm{~Hz})$. MS $m / z$ 361. Anal. Calcd for $\mathrm{C}_{20} \mathrm{H}_{11} \mathrm{NO}_{6}$ : C, 66.49; H, 3.07; N, 3.88. Found: C, 66.34; H, 3.00; N, 3.75\%.

3-Benzoyl-2-(thiophen-2-yl)-4H-chromen-4-one (10k). Yield $0.277 \mathrm{~g}(83 \%)$, m.p.=208-209 ${ }^{\circ} \mathrm{C}$ (EtOH). ${ }^{1} \mathrm{H}$ NMR $\left(\mathrm{CDCl}_{3}\right) \delta 8.22(1 \mathrm{H}, \mathrm{m}), 8.02(2 \mathrm{H}, \mathrm{m}), 7.75(1 \mathrm{H}, \mathrm{m}), 7.40-7.63(7 \mathrm{H}, \mathrm{m}), 7.03$ $(1 \mathrm{H}, \mathrm{m})$. MS $m / z$ 332. Anal. Calcd for $\mathrm{C}_{20} \mathrm{H}_{12} \mathrm{O}_{3} \mathrm{~S}: \mathrm{C}, 72.27$; $\mathrm{H}, 3.64 ; \mathrm{S}, 9.65$. Found: $\mathrm{C}$, 72.16; $\mathrm{H}, 3.55$; S, 9.50\%.

3-(5-Methylthiophene-2-carbonyl)-2-(5-methylfuran-2-yl)-4H-chromen-4-one (101). Yield of $1010.234 \mathrm{~g}(67 \%)$, m.p. $=190-192{ }^{\circ} \mathrm{C}(\mathrm{EtOH}) .{ }^{1} \mathrm{H} \mathrm{NMR}\left(\mathrm{CDCl}_{3}\right) \delta 8,22(1 \mathrm{H}, \mathrm{d}, J=7.9 \mathrm{~Hz}), 7.72$ $(1 \mathrm{H}, \mathrm{m}), 7.53(1 \mathrm{H}, \mathrm{d}, J=8.4 \mathrm{~Hz}), 7.40-7.45(2 \mathrm{H}, \mathrm{m}), 7.07(1 \mathrm{H}, \mathrm{d} J=3.4 \mathrm{~Hz}), 6.73(1 \mathrm{H}, \mathrm{d}, J=$ $3.7 \mathrm{~Hz}), 6.13(1 \mathrm{H}, \mathrm{d}, J=7.3 \mathrm{~Hz}), 2.53(3 \mathrm{H}, \mathrm{s}), 2.42(3 \mathrm{H}, \mathrm{s}) . \mathrm{MS} m / z(350)$. Anal. Calcd for, $\mathrm{C}_{20} \mathrm{H}_{14} \mathrm{O}_{4} \mathrm{~S}, \%$ : C, 68.56; H, 4.03; S, 9.15. Found, \%: C, 68.45; H, 3.90; S, 9.28.

3-(3-Nitrobenzoyl)-2-(furan-2-yl)-4H-chromen-4-one (10m). Yield $0.289 \mathrm{~g}$ (80\%), m.p.=186$187^{\circ} \mathrm{C}(\mathrm{EtOH}) .{ }^{1} \mathrm{H} \mathrm{NMR}\left(\mathrm{CDCl}_{3}\right) \delta 8.76(1 \mathrm{H}, \mathrm{s}), 8.42(1 \mathrm{H}, \mathrm{d}, J=8.1 \mathrm{~Hz}), 8.35(1 \mathrm{H}, \mathrm{d}, J=7.7$ $\mathrm{Hz}), 8.20(1 \mathrm{H}, \mathrm{d}, J=7.9 \mathrm{~Hz}), 7.78(1 \mathrm{H}, \mathrm{m}), 7.68(1 \mathrm{H}, \mathrm{m}), 7.60(1 \mathrm{H}, \mathrm{d}, J=8.4 \mathrm{~Hz}), 7.40-7.50$ $(2 \mathrm{H}, \mathrm{m}), 7.25(1 \mathrm{H}, \mathrm{m}) ; 6.56(1 \mathrm{H}, \mathrm{m})$. MS m/z 361. Anal. Calcd for $\mathrm{C}_{20} \mathrm{H}_{11} \mathrm{NO}_{6}: \mathrm{C}, 66.49 ; \mathrm{H}$, 3.07; N, 3.88. Found: C, 66.60; H, 2.96; N, 3.78\%.

Synthesis of 2-(furan-2-yl)-3-(phenylcarbonothioyl)-4H-chromene-4-thione (10n). Finely dispersed phosphorus pentasulfide (1.2 equiv.) was added to a solution of compound 6a (1 equiv.) in methylene chloride at RT, and the mixture was stirred for $4 \mathrm{~h}$ (TLC monitoring). After the end of the reaction, the precipitate was filtered off and washed with methylene chloride. The resulting dark-colored solution was filtered through a silica gel layer, and the solvent was evaporated on a rotary evaporator. The red-brown precipitate obtained was washed with cool ethanol and dried. The yield was 70\%. M.p. 216-217 ${ }^{\circ} \mathrm{C} .{ }^{1} \mathrm{H}$ NMR $\left(\mathrm{CDCl}_{3}\right) \delta 8.56(1 \mathrm{H}, \mathrm{d}, J=$ 8.0), $8.02(2 \mathrm{H}, \mathrm{d}, J=7.3 \mathrm{~Hz}), 7.78(1 \mathrm{H}, \mathrm{m}), 7.38-7.62(6 \mathrm{H}, \mathrm{m}), 7.22(1 \mathrm{H}, \mathrm{d}, J=4.0 \mathrm{~Hz}), 6.53$ $(1 \mathrm{H}, \mathrm{d}, J=1.8 \mathrm{~Hz})$. MS $m / z$ 332. Anal. Calcd for $\mathrm{C}_{20} \mathrm{H}_{12} \mathrm{O}_{3} \mathrm{~S}: \mathrm{C}, 72.27$; H, 3.64; S, 9.65. Found: C, $72.15 ; \mathrm{H}, 3.75 ; \mathrm{S}, 9.49 \%$.

\section{References and Footnotes}

1. (a) Cutting, W. C.; Dreisbach, R. H.; Azima, M.; Neff, B. J.; Brown, B. J.; Wray, J. Stanford Med. Bull. 1951, 9, 236. (b) Mentzer, C.; Meunier, P.; Lecocq, J.; Billet, D.; Xuong, D. Bull. Soc. Chim. Fr., 1945, 12, 430. (c) Cox, J. S. G. Nature (London) 1967, 216, 1328. (d) Orr, T. S. C.; Pollard, M. C.; Gwilliam, J.; Cox, J. S. G. Celin. Exp. Immunol. 1970, 7, 745.

2. Jovanovic, S. V.; Steenken, S.; Tosic, M.; Marjanovic, B.; Simic, M. G. J. Am. Chem. Soc. 1994, 116, 4846.

3. Grindlay, D.; Reynolds, T. J. Ethnopharmacology 1986, 16, 117.

4. Hirata, T.; Suga, T. Bull. Chem. Soc. Jap. 1978, 51, 842.

5. Womble, D.; Helderman, J. H. Int. J. Immunopharmac. 1988, 10, 967. 
6. Yu, D.; Brossi, A.; Kilgore, N.; Wild, C.; Alloway, G.; Lee, K. H. Bioorg. Med. Chem. Lett. 2003, 13(9), 1575.

7. (a) Bouanani, H.; Gayoso, J. C.R. Acad. Sci. Paris, Ser. C. 1973, 273, 399. (b) Saburi, Y.; Yoshimoto, T.; Minami, K. Nippon Kagaku Zaisshi 1971, 92, 552.

8. Huffman, K. R.; Kuhn, C. E.; Zweig, A. J. Am. Chem. Soc. 1970, 92, 599-605.

9. Cummings, R. T.; DiZio, J.P.; Krafft, G. A. Tetrahedron Lett. 1988, 29, 69-72.

10. Tang, L.; Zhang, S.; Yang, J.; Gao, W.; Cui, J.; Zhuang, T. Molecules 2004, 9, 842.

11. Rossollin, V.; Lokshin, V.; Samat, A.; Guglielmetti, R. Tetrahedron 2003, 59, 7725. Lacova, M.;El-Shaaer, H. M.; Loos, D.; Matulova, M.; Chovancova, J.; Furdik. M. Molecules 1998, 3, 120. 